Research, part of a Special Feature on Conceptual, Methodological, Practical, and Ethical Challenges in Studying and Applying Indigenous Knowledge

\title{
The social nature of environmental knowledge among the nomadic Wodaabe of Niger
}

Nikolaus Schareika ${ }^{1}$

\begin{abstract}
Pastoral nomads such as West Africa's Wodaabe are renowned for the impressive environmental knowledge they apply to successfully raise animal herds in arid and variable environments. We looked at such herders' knowledge not as based on individual learning and expertise but as ultimately social in the sense that it is formed, made available, and linked to pastoral decision making in the public and interactive space of permanent talking, discussing, and negotiating among peers. Drawing on theoretical ideas from science and technology studies, a number of concrete social situations of information management and pastoral decision making were explored in detail to reveal the distinctly social character of Wodaa6e knowledge. Special emphasis has been given to the institutional framework of knowledge exchange; the blending of moral values and empirical facts in particular statements of knowledge; the dialogic and collaborative nature of information procurement and assessment; and the contingency of decisions reached after lengthy rounds of discussion among herders.
\end{abstract}

Key Words: Fulani; local environmental knowledge; Niger; pastoral nomads; science and technology studies; West Africa; Wodaabe

\section{INTRODUCTION}

Environmental knowledge is of the greatest importance to pastoral nomads such as West Africa's Wodaabe. The well-being and prosperity of the cattle they live on depends on the smart and farsighted selection of migration routes and high-quality pastures under permanently changing environmental and political conditions. To make such selections, as much environmental and other relevant information as possible has to be procured, assessed, and fed into pastoral decision making (cf. Niamir 1990).

Systematic elicitation of the Wodaabe's knowledge demonstrates that these herders communicate an impressive amount of individual learning, but in-depth ethnographic study also reveals that it is not the individual actor's knowledge that becomes operational in pastoral decision making. Wodaa6e knowledge appears as ultimately social in the sense that it is formed, made available, and linked to pastoral decision making in the public and interactive space of permanent talking, recounting, asking, answering, doubting, contesting, vindicating, discussing, and negotiating among peers. Therefore, I persistently focus on the fact that environmental knowledge is contained in processes of social interaction, in which ideas are intersubjectively shared and shaped through utterances that speakers make publicly and to which other speakers publicly react. I take theoretical inspiration from the field of science and technology studies (STS), analyzing a number of concrete social situations of information management and pastoral decision making to reveal the distinctly social character of Wodaabe knowledge. Special emphasis will be given to the institutional framework of knowledge exchange; the blending of moral values and empirical findings in particular statements of knowledge; the dialogic and collaborative nature of information procurement and assessment; and the contingency of decisions reached after lengthy rounds of discussion among herders.

\section{KNOWLEDGE IN AND THROUGH ACTION: THE SOCIAL PRACTICE OF KNOWLEDGE USE AND GENERATION}

In his book Science in Action: How to Follow Scientists and Engineers through Society, Bruno Latour discerns two ways of looking at scientific knowledge. The first sees "ready made science" (Latour 1987:4). This is the conventional view of science that presents knowledge in objectified and coherently closed forms such as propositions, classifications, charts, models, or technical devices. These items of knowledge normally remain "black boxes": The dynamic, controversial, and contingent social processes that played a part in their creation are not scrutinized and revealed as important constituents of this knowledge. Moreover, such scrutiny is not defined as a crucial step in the study of these items of knowledge. According to this conventional view of science, the generation or "discovery" of knowledge can be explained by the fact that it is validated through experience.

The alternative way of looking at scientific knowledge, according to Latour, turns to "science in the making" or "science in action." It studies "facts and machines while they are in the making" (Latour 1987:13). Four traits of this approach are of immediate interest to the analysis of local knowledge. First, the focus is less on knowledge as already achieved by a scientific community, and more on the process of the creation and contestation of knowledge. Second, the analysis of this process is not couched in the language of epistemology, methodology, and reason alone, but in the language of sociology: The creation of knowledge is seen as embedded in relationships that actors establish and perform with each other through practice. Third, social practices relevant to the creation of knowledge are by no means limited to those that involve the application of reason. They include not only explicit quests for knowledge but also any other activity that is assumed to exist in social situations, e.g., the use of political authority, the calculation of costs, the following of established rituals, or the use of rhetorical means of persuasion. Fourth, the 
microscopic observation of social situations, particularly those entailing dispute and controversy, is the method used to produce detailed accounts of the processes of social interaction by which knowledge is created and asserted.

One might expect a family resemblance between Latour's approach to scientific knowledge and the perspectives taken in the by now immense literature on "local," "indigenous," or "traditional" environmental knowledge. Both look at knowledge in ways that defy science's self-image as purely based on facts of nature, methods of reason, and rules of logic, that is, things allegedly independent of society (cf. Agrawal 1995). Both examine how knowledge is linked to social groups, livelihood systems, and culture; how it articulates with areas of society such as religion, ritual, politics, morale, and resource management; and how it varies in form and content according to its specific cultural or historical context (e.g., Berkes 2008).

On closer inspection, however, one can see that the study of local knowledge has mostly stuck to what, paraphrasing Latour, can be called "ready made local knowledge" as opposed to "local knowledge in the making." Knowledge has variously been conceptualized as a resource for development (Warren 1991); as an adaptation to environmental or other external conditions (Knight 1980, Berkes et al. 2008); as an attribute or property of an ethnic group or a community (Warren et al. 1995); as derived from experience (Sillitoe 1998); as contained in forms and media unfamiliar to science, e.g., myths, bodily practices, land races, management schemes, and religious dogma (Wright and Dirks 1983, Richards 1985, McCorkle 1989); or as transmitted by tradition (Berkes 2008). These presentations can be interpreted as relativist stances that allow for culturally variable forms of knowledge that are as legitimate as science. However, they also resemble the conventional view of science in that they look at knowledge as a finished product with an objectified and nonnegotiated form (cf. Agrawal 1995 who makes a similar point). They do not explore the vivid, dynamic, and controversial social processes or the immediate situations of social interaction within and through which knowledge, be it scientific or local, is used or created.

The local knowledge literature does postulate a close connection between local knowledge and society or social structure. Its analyses, however, are mostly based on a model of knowledge creation or application that skips processes of social interaction. This model establishes a reciprocal relationship between two sides: On the one side, there is a unit that seeks or contains a certain kind of knowledge. This unit is of one of three kinds: an individual person, a whole cultural group, or a codified form of knowledge such as a proposition, a classification, a rule of behavior, or a story. On the other side, there is an element of nature about which something can be known, e.g., a herd of caribou, a forest, or a fish pool. The analysis then looks at how these two sides relate to each other, e.g., in which way the first represents and understands the latter or effects an adaptation to it. The crucial element that is omitted in this model is a detailed account of situations of social interaction in which local people present their knowledge to each other. There are a few isolated works that attempt to consider social interaction in the construction of indigenous knowledge: A tentative effort can be found in Berkes (2008), an early anthropological masterpiece is Barth (1966) on Norwegian fishermen, and Hutchins (1995) gives a comprehensive analysis of cognition as a group activity. There are also approaches that put an emphasis on performance (Richards 1993) or practice (Gadgil et al. 1993), but their concept of practice refers to humans dynamically engaging with natural resources and not to humans communicating with each other about these resources.

The reason for this state of affairs has partly to do with methods of data collection and the institutionalization of "local knowledge" as a separate field of often interdisciplinary research. Scholars of local knowledge seem to treat their object of study, i.e., items of knowledge, in just the same way that scientists treat theirs, i.e., items of nature. They perceive them as attributes of a given community of people that exist independent of situations of social exchange and are "there" to be captured by researchers for analysis or development (Johnson 1992; cf. the critique of ideas of an ex situ conservation of local knowledge in Agrawal 1995). I would argue by contrast that the "local knowledge" made available in conversations between researchers and local informants is shaped in form, structure, and content by the research encounter's peculiar social dynamics (cf. the earlier critical work of Randall 1976). The knowledge that local people make available to each other when dealing with a given task or problem is also shaped, differently though, by the peculiar social process through which this happens (cf. Akrich 2000; see also Barth 1975). Therefore, the "local knowledge" elicited from informants, e.g., a seasonal calendar arranged in tabular form, should not be treated as equivalent to what informs people when dealing with their environment in socially organized ways.

Latour suggests that we study knowledge in the making. However, this is only possible when the object of study is local people's procedures of socially producing and using local knowledge rather than the process by which researchers elicit items of knowledge. Therefore, following Berger and Luckmann (1967), I suggest theoretically and methodologically treating knowledge as ultimately social. This means that its form, structure, content, use, development, and communication develop within processes of social interaction. As Agrawal (1995) noted some time ago, such an approach to local knowledge can draw on the methodological and theoretical insights found in "The Sociology of Scientific Knowledge" (Collins 1983) and in the field of STS. This task is far from easy because STS embraces a variety of different perspectives, such as actor-network theory (Callon 1986, Latour 1991, Law 1992, 2012) and social construction of technology (Pinch and Bijker 1984, Bijker et al. 2012). It therefore presents an enormous wealth of research literature: Two classical collections are MacKenzie and Wajcman (1999) and Bijker et al. (2012). Moreover, STS is built on sophisticated systems of sociological thought such as Harold Garfinkel's (1967) ethnomethodology.

I will not engage in a thorough discussion of STS but simply start by noting three relevant points. First, Bruno Latour and and Steve Woolgar (1986) have taken inspiration from ethnographic field methods to study the social processes through which scientific facts are constructed in laboratories. Their key question concerned the way a scientific "fact" is generated through the social process of finding a consensus with regard to that "fact." It is now only fair to bring this question back to the place from which these scholars took their method. The processes that have 
been studied in the laboratories of chemists and that are relevant to the understanding of scientific knowledge can also be studied in the camps and bushland of Wodaa6e nomads. They are, as I shall argue, crucial to the understanding of these nomads' environmental knowledge.

The second point to be noted is the idea of David Bloor's "strong programme" aptly summarized by Pinch and Bijker (1984:401):

Its central tenets are that, in investigating the causes of beliefs, sociologists should be impartial to the truth or falsity of the beliefs, and that such beliefs should be explained symmetrically. In other words, differing explanations should not be sought for what is taken to be a scientific 'truth' ... and a scientific 'falsehood'. ... all knowledge and all knowledge-claims are to be treated as being socially constructed: that is to say, explanations for the genesis, acceptance and rejection of knowledgeclaims are sought in the domain of the Social World rather than in the Natural World.

From this point of view, then, the study of local knowledge cannot be reduced to demonstrating its adaptive or truth value. Rather, the social, often controversial, processes by which knowledge claims gain acceptance or are pushed through within a community have to be delineated.

The third point of interest is actor-network theory's concept of "heterogeneous engineering" (Law 1992, 2012) that invites us to study knowledge "as a product or effect of a network of heterogeneous materials" (Law 1992:381). Actor-network theory scrutinizes what certain actors do to "enroll" other human as well as nonhuman actors into a network of consensus. They do this by aligning the interests of others with their own. Any configuration of items within a network is seen as depending on the activity and effort that hold them in place and "prevent those bits and pieces from following their own inclinations and making off" (Law 1992:386). It is therefore necessary to look at exactly what kinds of heterogeneous items, human and nonhuman, are assembled in such a network and how these items attempt to link to each other.

\section{METHODS}

To adopt the STS perspective of knowledge as ultimately social and to study knowledge in action, the ethnographic method has to shift away from seeing knowledge as a fixed corpus that can be dissociated from social practice and systematized according to externally defined domains of reason, e.g., "botanical" knowledge as in the important work of Berlin (1992). It should turn toward examining the flow of social exchange that meanders through various themes and arguments, thereby exposing the knowledge by which that exchange is driven, as well as the knowledge created through that very exchange. The researcher has to refrain from defining domains of knowledge, e.g., botanical knowledge, and creating a research setting that reconstructs the expected or assumed characteristics of that domain, e.g., sessions of elicitation between informant and interviewer as described in Martin (1995). Rather, the researcher is to follow through situations of naturally occurring talk and social practice as it unfolds and make out what contributes to the sequence of events (Meyer and Schareika 2009), thereby seeing knowledge in action within its total context of social relations. Practically, it is useful to adopt the data registration techniques of conversation analysis (CA) and audio- or even videotape situations of naturally occurring talk (e.g., Have 2007; the use of the term "natural" as opposed to "researcher-provoked" talk is established in CA). The resulting data are an account of the social forms within which knowledge can be empirically documented in a given society and through which it can be intersubjectively shared among its members and, at the same time, with the ethnographer. Providing and analyzing such accounts will help us to understand environmental knowledge as contained, developed, and used in the dynamic flow of everyday social interaction.

I will present and analyze several verbatim transcripts of Wodaabe discussions (as in Fig. 1) to develop a number of propositions on the social nature of knowledge among the Wodaabe. The recordings were made during two years (1996-1998) of fieldwork that involved extensive participant observation among Wodaa6e groups in southeastern Niger (Schareika 2003a, b). Further anthropological fieldwork in the years 2000, 2004, and 2005 and analysis of a huge corpus of audio-recorded talk add to the ethnographic knowledge on which I draw (e.g., Schareika 2010a, 2011). Although pastoral decision making among the Wodaabe as well as other African pastoral societies is chiefly the domain of men, I expect women's voices to be fairly important within it. Their assessments of milk yields or drinking water quality, for example, enter pastoral decision making; however, the material I present does not allow for an examination of this particular social process. I hope to be able to make up for this in another article.

Fig. 1. Wodaabe herders discussing their next move.

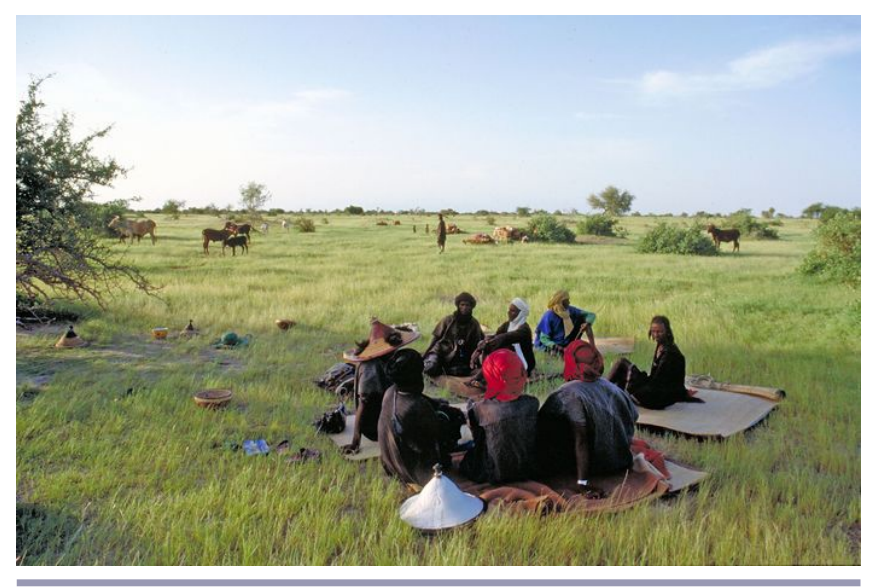

\section{THE WODAABE}

The Wodaa6e (sing. Bodaado) pastoralists are an extremely mobile group of Sahelian cattle herders living in Niger, Nigeria, Cameroon, Chad, and the Central African Republic. In the anthropological literature, they are renowned for their knowledge of the natural environment (ladde, "the bush") and the art of raising cattle (ngaynaaka; Dupire 1957, 1972, Stenning 1957, Bonfiglioli 1981, Thébaud 2002, Schareika 2003a, b, Krätli 2008). They are one of many culturally diverse Fulani societies that spread from Senegal to Sudan and speak the Fulfulde language. The Wodaa6e I present live in the southeastern corner of Niger immediately west of the shore of Lake Chad. Occupying grass and bush savannah with 200 to $300 \mathrm{~mm}$ of rainfall per year, these 
Wodaa6e specialize in raising large Zebu cattle (Bos indicus) that they complement with smaller herds of sheep (Ovis aries) and goats (Capra hircus). I have argued elsewhere that constant mobility is a means to optimize fodder quality and, consequently, the herd's reproduction rate (Schareika 2001, 2003b, Krätli and Schareika 2010): During the 3 months of the rainy season, the Wodaa6e of southeastern Niger move on every day or every second day; and during the 9 months of the dry season, about every week. Although it is safe to say that the Wodaabe of southeastern Niger aspire to live nomadically off large herds of Zebu cattle, there are also those who have lost their herds, for example because of the combined effects of drought and reduced access to pasture. In such cases, livelihood strategies often include farming (cf. Bonfiglioli 1990) or seeking jobs in the urban areas of northern Nigeria.

As generally reported for pastoral drylands in Africa, environmental and political conditions are variable and unstable, calling for continuous adjustment of strategy (Behnke and Scoones 1993, Scoones 1996). From failing rains to invading locusts, spreading cattle diseases, overpriced millet markets, armed rebels and thieves, greedy and/or malevolent state officials, farmers raking in the bushland's grass or extending their fields, rarely does a nomad lack problems that require clever decisions, creative solutions, and sometimes swift action.

The basic unit of pastoral production and decision making is the family household that consists of a man, his wives, their children, and the family herd on which they depend. A family household is enlarged and becomes more complex when the household head's sons are joined by their wives and have their own children (cf. Bonfiglioli et al. 1984). The pastoral family household is the nucleus of Wodaa6e clan society that displays the characteristics of segmentary lineage organization (Dupire 1996). Although independence of the pastoral household has often been referred to as a necessity of the nomadic livelihood (e.g., Stenning 1958, Gulliver 1975), the need for security, mutual assistance, information exchange, and, of course, pleasure leads Wodaabe households, independent as they are, to integrate within migratory groups (Bonfiglioli et al. 1984, Schareika 2010a). Thus, by gathering around a well or moving along the same pastoral trajectory, a couple of Wodaa6e households normally share some common space and coordinate their pastoral decisions. The composition of migratory groups is based on patrilineal kinship, usually, though not exclusively, with brothers or paternal cousins keeping closely together. Although a migration group can easily change in composition, the families of a migration group normally share their day-to-day affairs and visit each other regularly, their camps being set up several hundred meters apart.

\section{THE DIALOGIC CONSTRUCTION OF ENVIRONMENTAL KNOWLEDGE}

I present and discuss empirical findings that substantiate the proposition that the locus of Wodaabe knowledge acquisition, evaluation, and use is not the individual's mind talking to itself but the group of fellows, family members, kinsmen, and neighbors talking with each other. One type of communicative event that lends itself to detailed consideration is the discussion of possible pastoral migration routes and targets that unfolds when scouts (seewtotoowo) come back from their exploratory missions (seewtunde). There is a specific term for this discussion, kinnal (literally "greeting"), but this does not mean that the discussants always keep strictly to the point. Rather, they range over a variety of themes to make their points in indirect ways. What is distinctive for the kinnal is that the talks lead to a decision, i.e., the decision to move to this or that destination.

The basic structure of the kinnal is the following: The elders of households that form a temporary migration group (kinnidal) and that are usually close kinsmen come together in one of their camps. Their adolescent and adult sons are also there, particularly when they communicate information that they have gathered as scouts. Kinsmen from other migration groups who are visiting them or passing by will also attend. As will be seen in the excerpts cited subsequently, it is through this social structure of consultation that various pieces of knowledge and knowledgeable judgment distributed among the group's members are brought together, intellectually processed, and finally synthesized. This synthesis is expressed first in a conclusion, second in a proposal for action, and third in calls for implementing the proposed course of action. The mood of the discussion is one of critical attentiveness in which everybody is invited to exercise rigorous, sometimes even aggressive control over the accuracy of information, the trustworthiness of sources, the consistency of judgments, and the wisdom of proposed decisions.

The kinnal is thus a social institution geared toward putting distributed knowledge together and thereby transforming it into an assessment of the environmental and pastoral situation that each individual herder on his own could not have generated. At the same time, however, it constitutes, as always when the Wodaa6e gather as a group, a moral force, in that it defines how a herder should act in the given situation if he wants to be credited with the virtues of farsightedness (hakkiilo) and patience (munyal), and if he wants to be seen as a person who cares for the cows that he has been endowed with by his lineage group. Moreover, the kinnal constitutes a political force in that individuals join in the effort to reach a decision collectively; the fact of participating in its making renders each individual herder an agent of the decision as well as a subject of the collectivity he had joined to become this agent. Thus, in the kinnal, environmental knowledge makes its public appearance in the form of a dynamic and engaged debate about bits and pieces of information gathered by various herders and the conclusions to be drawn from them. This debate is pushed and shaped by a rigorous search for truth and certainty, but also by the whole social and institutional setup within which it is organized and within which it makes sense for the herders.

Within the social situation of the kinnal, the herders are, of course, not simply engaged in an intellectual task of establishing and assessing facts about pasture lands. Rather, their talks are part of a serious process of decision making on the basis of which capital, on the order of, say, 6 herds of fine Zebu cattle comprising together 300 animals, associated herds of sheep and goats, and families with altogether 60 people, will be moved. When debating where to move to next, each herder in a group of kinsmen and peers is therefore aware of the potentially fatal consequences of an imprudent decision. In addition, at stake is not only the physical well-being of his cattle and people, but also his position within lineage society. Will his contribution to the deliberations be acknowledged or rejected? Will his voice be heard or interrupted 
and discounted? Will he be a leader or a follower? Will the decision making contribute to his renown as a person of farsightedness and self-assertion, or will it place him in the lower ranks? What will he do when the decision does not please him; will he leave the migration group or stick with it on a migration route with which he is not satisfied? For the herder, each decision-making process is thus an instance of social practice that makes and defines him and that puts him on display as part of his family, his peer group, his lineage, and his community of nomadic peoples. It is now time to analyze just what happens in a kinnal.

\section{Establishing a fact about a flood area}

It is 16 August 1997 in the middle of a rainy season that has by no means been an easy one. The rains did not set in properly in the savannah of southeastern Niger, so at the beginning of the rainy season in May or June, most nomads moved to northern Nigeria to let their cows enjoy green grass (Schareika 2003a, $b$ ). Now coming home, on a trajectory that by the end of September will have led them to the dry season plains around their favorite wells, the nomads realize that many of the returning herds carry contagious diseases. The rains in southeastern Niger have remained mediocre until now, so many herders are in a quandary. Where there are no diseases, there is no grass; where there is grass, there are also the disease-carrying herds. The migration group around the wealthy herder Nyaleega has assembled to check its options.

\begin{abstract}
Mbohori: This is quite bad. And where can one move? What goes [from a certain point in the west] in direction to the dunes [i.e., north] we don't see where a herder can drive his animals and come back, that's for sure. But if it had been from here, to the north from here one could have found some grass scattered here and there.
\end{abstract}

\section{Rebo: On [the flood area] Nga Salkiiji?}

Nyaleega: Nga Salkiiji has got no water at all, I have heard (but I have [only] heard it). Has got no water at all. Whose words? The words of Garga, younger brother of Kootala, he came from there and installed his camp between Nga Buddere and Ngel Gunju. The other day we met in the west of here where you you have seen us make camp in the place of the Ngaya'en; we left them and they looked after the donkeys. When Garga came to the place of his sheep, we spent the afternoon there. He told me: here the lack of rain drove them towards Nga Salkiiji. He said: From the very first day it has not been inundated at all. If you go up north to the point where information is scarce. The lack of rain drove them away, he has not heard where water is to be found. This is what Garga said. Since you see herds of cattle coming here in single file...

\section{Rebo: $M$ hmm}

Mbohori: Isn't that on the northern route?

\section{Rebo: Hmm [yes].}

Mbohori: No, that has not got any rain.

In this passage (see Appendix 1 for text passages in the original Fulfulde), the reader is not confronted with something one could call "Wodaa6e knowledge" as it may appear after several exercises of analysis and ordering of data elicited by the anthropologist.
Rather, this is natural talk registered on tape and transcribed in simple analogy to its course in time. As such, it confronts the observer with something one could call the "Wodaabe machinery of knowledge production in action." A problem is posed: where to go with the herds in the current very unfavorable situation. A solution is suggested for testing: going to a place called Nga Salkiiji. The knowledge machine now shifts into its next gear with a holder of some piece of information, Nyaleega, advocating the test. Nyaleega says Nga Salkiiji has got no rain, which would disqualify it as a place to go. However, he qualifies this information: He has only heard it from talking, he has not seen it with his own eyes. This makes the information less trustworthy and calls for further critical testing. Moreover, in making this qualification, Nyaleega lessens the responsibility he is ready to accept for the given statement. Should it turn out to be untrue, he would not be blamed.

Thus, Nyaleega cites his source, Garga, and adds precision: Garga the younger brother of Kootala. He then goes on to explicate the potentially falsifiable circumstances of his getting in touch with his source: where, when, and by which coincidences he and Garga met. Finally, Nyaleega reports the details of Garga's communication. These make clear that Garga has not simply reported a lack of rain in Nga Salkiiji, but that he has experienced it and reacted accordingly in his capacity as a herder. There is a further inquiry as to whether one is really talking about the region to the north, which is affirmed. Then, it would seem, enough bits of information have been brought together and consolidated that a definite proposition of truth can be established: The northern region of Nga Salkiiji has got no grass and hence does not constitute an option for the next migratory move. This collectively established certainty calls for the presentation and testing of an alternative. Nyaleega again takes the lead.

\section{News of rain from a doubtful source}

Nyaleega: As to me, my talk of today you won't like it. It will turn out to make man a liar. But Egere came from Haadndu [a borehole], we spent the afternoon together in the market. So, the talk, but it's not a herdsman who told it, you won't tell it to the clan. It is no good.

He told me, behind Haadndu there is no fresh grass of the better kind but the rains haven't failed either. There was no fresh grass [from where he came] until he reached Kanadaa [a borehole drilled by Canadians]. He said: To the north of Haadndu behind Kawlayel, rain has come these days (indeed we had seen one big shower). He said from there on rain has covered the bush right to the big flood area of Haadndu; there it break off.

He said, the area to the east of the dune [the shore of Lake Chad] - this is what Egere told me. He said, is full of young green shots; it looks like fresh grass. I asked, will the cattle go there or not? He said, the cattle will go for sure. After our chat there is no one whom I have told these news. I know that I don't trust him.

Mbohori: The talk of Egere?

Nyaleega: The talk of Egere. He is no herdsman.

Kebbe: Ay this cloud, the one of the market day, there where it came from will have received rain. 
Nyaleega: He said, the cattle will come down [to this area] for sure. He said, my good fellow, I am not a herdsman, I am a man from town. I told him: No all herdsmen are one [i.e., the same]. He told me: On the dune Tribulus terrestris has come up, in the clayey plains though, grass has come up. This is what Egere told me. Told us lies, told us the truth [- we don't know].

Laabi: Mulliwol said, there is [grass] ... but a man who has got sheep won't go, the Ndoowi'en will take them. The Ndoowi'en will take away a man's sheep.

Nyaleega: The sheep will be taken away, kay there will be fighting.

Nyaleega starts by naming the fault he is going to commit, thereby demanding impunity from it. He is going to cite intelligence that should not be distributed within the clan of Wodaa6e herders because it is coming from a nonherder and therefore from a source that is not worthy of further consideration among the peers. However, apparently the situation is too bad and the news too good to stubbornly follow the etiquette of clanship. Egere, the source, has sighted a big rain shower and the grass that came afterward in the region to the north and east of the borehole of Haadndu. He thinks the grass is good for cattle. Nyaleega, however, repeats that he does not consider Egere a trustworthy source. Mbohori's inquiry seems to consolidate Nyaleega's disdain of Egere, but their nephew Kebbe makes a statement that supports Egere's proposition: The big cloud that they, the Wodaabe clansmen and experts of the bush, saw on the market day was clearly indicating rain. Kebbe's words encourage Nyaleega to lessen his contempt for Egere by saying that Egere himself acknowledged that he would not want to pass as an expert on herders' matters. Nyaleega also invokes Egere's opinion that other herders would take advantage of the grass. Then, Nyaleega's younger brother, Laabi, brings in what he has to contribute. There is a further, reliable source, namely their clansman Mulliwol, who also said there was fresh grass in that region. However, just one instant later, Laabi shatters all hopes by raising another issue. The place is too dangerous to go to because young Fulani (anti-) rebel fighters would confiscate the nomads' sheep. This is accepted as ruling out the option just discussed.

In contrast to the dogmatic nature that is often attributed to local knowledge, as contained in the concepts of wisdom and tradition, we thus see Merton's "organized skepticism," and also "communism," characteristic of science (Merton 1942) institutionalized in the Wodaabe form of knowledge creation. The power of the Wodaa6e machine of knowledge production is not that it has been fueled with forever valid statements of truth, but that a wrench is repeatedly thrown into its works, thereby redirecting it on its course of inquiry (for similar findings on hunter-gatherers of the Kalahari, see Liebenberg 1990).

\section{Move first, then see}

Obviously, Nyaleega's migration group's machine of knowledge production has so far worked properly. By systematic assembly of parts of distributed knowledge, it has exposed every migration goal proposed as potentially fateful. The machine's defect is only that it has not spit out a passable option for the group. The method of sitting together and judging intelligence to move herds and people seems to have produced nothing but reservations and barriers. So, in the next situation, we see Nyaleega reverse the Wodaa6e principle "think carefully, then move" into "move herds and people first, then see and judge." The Wodaa6e have a concept for this kind of move into uninspected territory, which is called bumngol ("blind move").

Nyaleega: Now, what we are going to do: Here, everywhere to go now is far away. As to me, when we see it's like we are squeezed from all sides, what I say we do, let us move on. But when we move on let us set off for the big pond that we spent the dry season watering (our beasts) [i.e., the pond Nga Loppiri].

When we get to that big pond and find something like Tribulus terrestris and the high-grown [meaning not optimal] Cenchrus biflorus of which they have spoken, we install our camps. Let us then strive through the bushlands there, let us see what they look like, there we get the chance to strive further on. Let us explore the bush to find something, let us look what is there, let us see what is there in the bush.

Rebo: This pond, though, is it possible to get there?

Nyaleega: Yes.

Rebo: But this pond ... people don't like it.

Nyaleega: The thing is simply that it is not blocked by animals. The people with foot-and-mouth disease have passed it. Those with foot-and-mouth disease have passed it.

Kebbe: The people with foot-and-mouth disease are in fact following us.

Nyaleega: The people with foot-and-mouth disease have passed it.

Muudi: Isn't it the one (pond) over there?

Nyaleega: That's it, it's the only one.

Gayro: Even before the people with foot-and-mouth disease have been around Nga Loppiri.

Nyaleega: To the south?

Gayro: Yes indeed. If they haven't arrived at this pond yesterday they are about installing themselves there now. Even before Ngukoori and the Jiijiiru have been there. They are many and that for a long time. The people of Ngambijaari are there too. This pond, though, all people that went to the market have seen it, this one, one will not want to install one's camp there. These Tribulus terrestris that we have seen, they aren't there...

Nyaleega: They aren't there. It's only that tall Cenchrus biflorus.

Gayro: The tall Cenchrus biflorus does not exist either. It's only the name of it. Didn't I spent all yesterday morning there? The Ndoowi'en, too, didn't find a place to install themselves.

This passage shows that Nyaleega's thrust based on inverting the principle "think carefully, then move" into "move first, then see and judge," is swiftly brought under control by some bullets of 
criticism of the type that the Wodaabe knowledge machine fires so easily. Nyaleega has accelerated the machine by moving from cautious deliberation to spirited call for action, using the formula "let us do!": "let us move," "let us set off," "let us explore the bush," and "let us see." However, Nyaleega is restrained from packing the donkeys for a move and drawn back into the debate, with a question that forces him to defend the statements of truth that justify his call for departure. Will the pond that he suggests heading for really satisfy their needs? Nyaleega argues that the herds with foot-and-mouth disease have passed the pond so that there is no longer any danger, but the group pulverizes his optimism. Starting with a negation of Nyaleega's statement in general terms, i.e., the herds with foot-and-mouth disease are currently staying at the pond, precise information concerning the names and migration histories of herders is mentioned as its proof. Even more information concerning the low quality of grass is added so that finally Nyaleega repeats the refutation of his own call for action: The young shoots of the herb Tribulus terrestris are not there at the pond. It is only tall Cenchrus biflorus. Finally, his son Gayro adds that even the tall and therefore barely usable grass Cenchrus biflorus is only a fantasy.

\section{Assessing facts in social order}

The discussion of pasture and migration can sometimes turn into an awkward situation for the speakers because they have to combine two incompatible theories of truth. The dominant theory of truth in Wodaabe verbal exchange is related to the practical task of running a pastoral family and a wider lineage group. It is normative and simply states: "What the fathers and paternal uncles say is true." When they say: "A herder must look after his cattle day in, day out," there is nothing left for their sons and nephews to argue about. This theory of truth also implies that it is the elders who synthesize various empirical observations reported by the scouts to form judgments that are the basis of decisions. The other theory of truth that appeals to all Wodaabe as passionate empiricists and nomads is related to the intellectual task of analyzing a pastoral environment. It is empirical and simply states: "What you see is what is true." This means that somebody who can produce convincing evidence that he has been part of a situation that, by all standards of common sense, allowed him to see something, is believed to tell the truth when he reports on that thing. By contrast, all statements of truth are considered probable lies when based on indirect sources that are mediated only by the speaker, especially when he relates things heard in conversation with others.

Now, rather than the fathers and paternal uncles, it is actually the many sons and nephews who move around a lot in the bush and are able to see things with their eyes. In discussions of the environmental situation, they often have important information to tell, and it is not always easy or even possible to separate observations from judgments. In the following passage, Kebbe, the young nephew of Nyaleega, makes a statement of fact concerning the relative spread of foot-and-mouth disease in the region, which is of crucial importance to the migratory choices of his uncle's group. However, right after that he adds a judgment that sets that statement of fact within the larger context of pastoral wisdom. There is nothing to fear more than the foot-andmouth disease, he declares. Realizing that he has exceeded what is the appropriate role for him in a talk with elders, Kebbe quickly qualifies his utterance.
Gayro: So, in front (west) of the small dune is the other guy, on the dune. He and Gado.

Nyaleega: Does he also have foot-and-mouth disease?

Gayro: No, Kedi has got no foot-and-mouth disease ... I met with his migration group.

Kebbe: The location where we are, in front (west) of it, the cattle will find no place to be installed. For sure one has to be afraid of the foot-and-mouth disease and also the fever. But here it is worse. Me, though, I am not a herdsman, I am not looking for pasture or anything else.

Nyaleega: My dear Kebbe, the seeing of things is all the same.

Kebbe: When someone is looking, father of Muudi, but he who doesn't even put the animals out to pasture, does he know what they need to graze in order to fill their bellies?

Nyaleega: But you are a herdsman, you have nothing in common with someone who doesn't put the animals to pasture.

Kebbe: But for sure, when a man is not afraid of this disease, when he is not afraid of the foot-and-mouth disease, when he is not afraid of the fever ...

Nyaleega: This is in fact what a man fears.

Kebbe thus steps back from the interpretation of his factual statement by adding that he is not a herdsman, that he is not a scout, that he is indeed nobody. His uncle reassures him in a posture of benevolence that, no, he is a real herdsman and his eyes are capable of searching the bush. Kebbe then repeats his judgment in a more questioning and less self-assured style so that his uncle is given the occasion to make the final and authoritative statement of truth: The foot-and-mouth disease is indeed that of which one has to be afraid. We thus see two superimposed spheres of social activity propelling each other reciprocally. First, an uncle and a nephew negotiate in the context of a collective elucidation of pastoral conditions and assessment of migratory options (social sphere 1). By doing so, they negotiate their particular relationship and the elder-youngster relationship in Wodaa6e society in general (social sphere 2). The outcome of this superimposition of spheres is that a youngster's important piece of information and its implicated judgment, i.e., Kebbe's statement, are fed into the opinion-forming process without compromising the elder's prerogative to interpret and generalize.

\section{THE SOCIAL PRACTICE OF FINDING GRASS WITH} CATTLE

There is even more to this merging of intellectual with practical social things. In the end, the herder must be able to execute his decisions by allocating work tasks. When debating decisions, he must be focused on the objective that his dependents and peers really do what, according to a knowledgeable evaluation of the situation, needs to be done, for example that his sons really look after the animals and guide them safely to some selected pasture site instead of amusing themselves in the next market. Because knowledge and action are almost inseparably connected for the herder, the exchange of knowledge, therefore, often turns into a bundle of further directives and devices to ensure action. These 
include rules, values, norms, and moral instruction. It is, in fact, quite difficult to analytically undo this bundle because, on the one hand, the exposition of some piece of knowledge can be used as a vehicle for moral instruction, and on the other hand, moral instruction can be the form within which some important piece of knowledge is conveyed and translated into action (cf. Ingold 2000).

In some cases, it is striking how redundant and simple, or even banal, the pastoral and environmental knowledge expressed in the utterances of a conversation seem to be. When looked at as a moral discourse, however, these utterances become understandable as a quintessential part of a system in which environmental knowledge, practical action, social structure, and moral instruction are inseparably merged. The following extract from a Wodaabe conversation is a case in point. A group of men spent the afternoon of 11 March 2004 together as they usually did, in the shade of a tree. When the case of a kinsman who had lost most of his herd was mentioned, an elder in the group, Baaki, started to deliver this advice to those who would be successful herders:

Baaki: The cattle of a person whose plan is no good at all, a person who's plan is no good at all won't see it [i.e., cattle] until the end of days.

A person who's plan is no good? He is looking for three things:

First he wants to have money, he says only when money is plenty in his pocket he will go out to see people. This one, he will not have a calving cow, he will not have a bullock to castrate.

Second, he loves talking, talk is all he wants, he will not be seen by his own herd until the day the land folds up.

Third, the third thing, Mbohri, is, he does not go out to look for grass, you won't find him with a calf rope full of calves in front of him until the day the land folds up.

When one says of somebody he castrates four, five or even six [bulls] on one occasion, he castrates ten or even more on one occasion, then it's not money [he is after] - when you see that he castrates these bulls, he is not looking for money. The one looking for money will sell every newborn bull and put the money in his pocket. So, until the end of days, when ever you meet him, you will find him strolling around alone. This is true for all times, there is no one that the cows detest, only the one with a dangerous plan. There is no one they dislike.

Baaki's emphasis is not on what one has to know about grass, trees, water, animals, and diseases to make one's cattle advance; rather, his emphasis is on the disposition and character of the herder. What is important is an uncompromised readiness to invest effort and engage oneself wholeheartedly with what cattle need to prosper: grass. Prosperity (risku) is a crucial social value, and keeping a few massive and fine adult oxen within one's herd is the ultimate display of pastoral success, i.e., showing that one could afford to not sell them as young bulls. Seeking, instead of grass, the pleasures of spending one's time chatting with peers and one's money on shortterm consumption is morally belittled and revealed as a most dangerous threat to prosperity in herding and in social life. For Baaki, it is a herder's poor character and, by implication, poor effort and engagement with his herd that will bring him down.
Baaki obviously sees a need for moral instruction to shape the young men's minds (cf. Watson-Gegeo and Gegeo 1990) and make them act as grass seekers. In the following, I make use of the concept of "heterogeneous engineering" noted previously to elucidate this form of moral instruction as being part of a particular system of environmental knowledge. Following the perspective of actor-network theory, this system can be seen to consist of a configuration of "heterogeneous materials" including herders, their utterances, cattle, and grass. I argue that, in operation, these elements form a system of continuous experimentation on the use and, through that use, discovery of pastoral resources. Moral instruction is the way in which herdmanaging elders enroll their sons and nephews into this system, or "network." It serves to align the interests of the latter with those of the former, i.e., the elders who care for the whole system's performance (see Turner and Hiernaux 2008 for an analysis of current trends in the social relations of herd management in western Niger).

Baaki admonishes the young men to go and "look for grass" (raara geene). One could imagine that he hereby refers to a two-step process. First, the young herders would make use of existing Wodaabe environmental knowledge by going out and identifying the optimal grazing spots that are currently available. Second, they would bring the animals to these spots to take advantage of the grazing. According to this scenario, received environmental knowledge would precede action. It would permit accurate predictions of pasture quality that in turn would allow herders to drive their animals to the best pastures. Wodaa6e pastoralists are certainly able to disclose indicators for good pasture, and their capabilities as scouts have been acknowledged (Bonfiglioli 1981, Schareika 2003b; see also The dialogic construction of environmental knowledge). However, I think such a two-step scenario that separates knowledge from action misses some crucial points of the Wodaabe herders' method of grass finding.

In fact, Baaki calls for raara geene as a continuous activity in which, as a matter of principal, the currently grazed pasture is judged potentially inferior to some other patch of potentially superior grass that lies ahead waiting to be found. A herd of cattle must be brought to that supposedly superior patch to test the hypothesis that it is indeed better. This principal is nicely caught in the often-heard phrase: raara to buri ("to look where it is better"). Knowledge about which grass is good for cattle, therefore, does not simply exist as a growing corpus of statements about grass or as human expertise and capability in identifying it. Knowledge of grass has to be revealed over and over again as a matter of fact, in a continuous experiment consisting of the frequent moving of the herd from one place to another.

The result of this experiment manifests itself in the belly of a cow, and the only language with which definite knowledge about grass can be spelled out is the language of bodily signs by which the cow tells the herder what the grass is doing to her (cf. Moritz et al. 2013). The cow, therefore, is a partner in a method of knowledge seeking that is carried out by an interspecies research team. This team operates by incessant experimentation with grass. Within the team, the role of the herder is to be permanently oriented toward seeking new, possibly superior grass, according to the motto raara to 6uri. That of the cow is to digest new, possibly superior grass to reveal its relative quality. The knowledge of grass 
so created is relative in the sense that it methodically builds on the comparison with grass that the cow has consumed before.

Moral instruction is crucial for this method of knowledge seeking because the human actor will only play his part properly when he can resist the temptation of sharing company with his peers rather than his cows. In principle, young Wodaabe herders already share their fathers' concern for the well-being of the family herd. At birth they have received ritually confirmed ownership rights to animals from their fathers' family herd (Dupire 1996, Schareika $2010 b$ ). These assets are supposed to form the basis of their future lives as married household heads. However, there are plenty of stories circulating in the camps about young men who have sold these and further assets. Therefore, elders like Baaki obviously see a need to constantly form the younger herders' disposition and character through incessant moral discourse such as that cited previously. Thus, the elders encourage them to invest their effort in constantly looking for grass so that the knowledge of grass is revealed in the signs of a cow's uninhibited appetite, glossy coat, massive body, steady breathing, agile spirit, and concave rumen, as well as in a calabash full of milk. Nomadic movement, therefore, is not a journey from a point of departure to a point of destination. It is a permanent state of being because it is the method in a socially organized and experimental system of knowledge acquisition. Each step of pastoral migration delivers a fact in the shape and spirit of the cow; a hypothesis that, again, the grass somewhere else is better; and a need for a test, performed by moving toward that grass to see what it does to the animals.

Building on works that ask what people do socially by the use of words (e.g., Austin 1962, Duranti 1997, see also Schareika 2010a), there is a complementary pragmatic analysis to be made of Baaki's speech. Although only Baaki talks in the passage cited previously, there are four actors who are relevant in understanding his speech. These four actors are the foundations of an architecture of rhetoric performance that is quite common among Wodaabe men. There is first a kinsman who is not present but who, as a kinsman and Bodaado, shares the world of practice and morale of those present in the conversation. This means that his deeds can be imagined as the possible deeds of those who are present and are morally judged in the same way. In the case of Baaki's speech, this kinsman is the one who had lost his cattle.

Second, there is the speaker, Baaki, who delivers a story, some piece of wisdom or proposition, or an evaluative statement. Third, there are the people who are addressed by the speaker through gesture, touch, or gaze; being named; or simply sharing the space of those who have a dialogue (cf. Meyer 2010). In most cases, this is a mat (daago) spread out in the shade of a tree. These are the speaker's peers, roughly sharing the same age and social position of married and elder household heads (maw6e). In the talk cited previously, this is Mbohori, Baaki's younger brother. Mbohori himself is an experienced, devoted, and successful herder just as Baaki is. One can safely assume that none of what Baaki says is new or revealing to Mbohori. It is also clear that Mbohori needs no moral instruction. He has probably also heard his brother dwelling on this theme on literally hundreds of prior occasions; on some of those occasions, I was also attending the scene. Thus, Baaki's talk does not make much sense when one assumes that Mbohori is the only or most important addressee.

Fourth, this brings me to those who are the real addressees, the adult or adolescent sons and nephews of the speaker, i.e., the youngsters (bilki'en). They occupy their own tiny space of mats and shadow some meters away from the elders. From their separated place, they listen to their fathers, uncles, and other elders talking with each other. However, what is said is at least partly, and sometimes even mainly, an educating, instructing, and disciplining message to these youngsters. This flow of talk from one group of men to the other thereby establishes the essential axis in the Wodaa6e architecture of rhetoric performance and moral instruction.

What seems to be ingenious about this rhetorical architecture of moral instruction is that the elders talk indirectly to their sons and nephews. The elders engage in a cooperative, dialogic effort of piling up stories, examples, pieces of wisdom or propositions, lessons, and evaluative statements. When the elders' sons and nephews are drawn into the persuasiveness of the dialogic style, the youngsters get few chances to bring in their own or even opposing points of view. Quite to the contrary, when the elders tell the stories of kinsmen who are not present, they create of them a sort of dummy that the whole group, i.e., elders and youngsters together, can comment on in a mood of moral agreement and collective indignation or admiration. Thus, instead of addressing their sons and nephews directly, thereby bringing them into a constellation of confrontation, the elders encourage the youngsters to build with them a coalition of moral agreement and join in the refutation or praise of the dummy that is under moral scrutiny. In other words, by creating a common target of moral evaluation, a potential relation of opposition between elders and youngsters is turned into a relation of identification of the youngsters with the elders' cause.

Baaki's speech on the conditions of success in herding thus points to the social structure of a system of knowledge generation. On the first level of this system, the cow and the herder establish an experimenting research team that seeks and digests grass to assess its quality as it materializes as body fat and milk. On the second level, moral instruction by the elders shapes the disposition and character of the young herder so that, of his own accord, he embraces his role as a grass seeker.

\section{CONCLUSION}

The very idea of local environmental knowledge is built on the assumption that the knowledge humans hold is linked to their particular social condition and to the social forms through which they may pass it on. I argue that the idea of the social nature of local environmental knowledge should be deepened by drawing on ideas found in STS.

Knowledge, then, must not be studied by abstracting it from the social bodies within which it lives and thrives. The emphasis must not be exclusively on the relation between a system or corpus of knowledge and a task of environmental management. Rather, from the very beginning of the research process, local environmental knowledge should be studied as contained, created, and realized, or "constructed," in dynamic processes of social interaction. Starting with this theoretical and methodological proposition, I elaborate five general points for Wodaa6e environmental knowledge.

First, real-world utterances that can be observed in naturally occurring talk among herders do not necessarily convey only one kind of meaning; rather, they assemble multiple layers of meaning and thus blend statements of knowledge with verbal forms of 
social action. They are at the same time, for example, classificatory, propositional, evaluative, moral, exhorting, and incentivizing. Because Wodaabe environmental knowledge is part of a practical activity, and not of a purely intellectual project, propositions about nature merge with forms of talk that are geared toward socially organizing a practical activity like driving a herd of cattle to new pasture.

The second point is that Wodaabe environmental knowledge does not exist in individual isolated reasoning or in collectively held but fixed forms of storage, order, or abstraction. Rather, it lives in a continuous flow of conversation and dialogue that not only brings together widely distributed pieces of knowledge, but also serves as an unrelenting machine of criticism, refinement, and intellectual experimentation. This allows systematic separation of the more and the less promising options for future pastoral movement. This dialogue also serves as the institutional frame within which the nomads' wealth of information and art of reasoning are tied to the political realm of collective decision making, without which they would be barely meaningful to the Wodaabe.

Third, the rounds of discussion are the nomads' way of dealing with the many uncertainties characteristic of pastoral environments. For an individual herder, it is simply not possible to assemble by himself all the knowledge that is potentially beneficial to his search for options. Every talking round is but a node within an enormous network of information exchange that covers the entire pastoral region as well as a huge number of topics and stories of herders' experiences. Bits and pieces of information from all directions and sources enter these discussions and are subjected to critical evaluation. The critical alertness shown in the talks reflects the general condition of uncertainty as much as the pastoralists' continuous effort to handle it. The talks furthermore constitute moments of creativity, innovation, and mutual learning; a collective of speakers puts bits of information together to transform them into knowledge and jointly accepted options for action. These can be the choice of migratory destinations, but also ideas for adaptation and change of the livelihood system as a whole.

Fourth, some of the knowledge-generating capacity that nomads use does not rest on individual or collective reasoning or wisdom passed on through tradition. Taking up the concept of "heterogenous engineering" from actor-network theory, I have argued that the Wodaabe's environmental relation and household routine of frequent nomadic movement constitutes an experimental setup that continuously delivers comparative assessments of grass quality and deliberately refuses to specify a body of fixed general knowledge about grass. This setup is composed of various family members, cattle, grass, and other components of the bushland. It also comprises the particular relations, practices, and values, such as the "search for the better," through which these elements are connected. One quintessential element in this setup is the human grass seeker who has to be mobilized and enrolled into the experimental setup through communicative processes such as moral instruction. The knowledge of what constitutes high-quality grass, i.e., grass that makes cattle prosper, is thus derived from socially organizing a relationship of continuous experimentation and comparison between herders, animals, and plants.
The fifth and last point is that the very structure of the social group, and the institutional framework within which the herders' conversations unfold, shapes how conversations unfold and, consequently, what gets established as truth. Thus, in the case of Baaki's dissemination of general pastoral wisdom, the social setup induced the younger men's passive acceptance of the seemingly eternal truths of the elders. In the case of Nyaleega's search for pasture, by contrast, the kinnal structure encouraged the youngsters' critical opposition toward the elder's presentation of assumptions and suggestions. This happened, however, in such a way as not to compromise the superior authority of an elder and renowned herdsman.

The arguments that I have developed have some wider implications, two of which I would like to point out. The first concerns pastoral development. Pastoral nomads are widely admired for their environmental knowledge and art of livestock keeping. These are, however, systematically linked to the whole setup of social institutions within and through which herders such as the Wodaa6e organize their relationships with the environment, their animals, and each other. Maintaining or developing these social institutions not only implies enormous effort on the part of the nomads, e.g., Baaki's unremitting moral instructions to the young are only one tiny episode, but also presupposes a legal space for local communities' self-organization within states such as Niger. How the provision of such space can be harmonized with state goals such as increased formal education and schooling or land reform is an important question to be addressed.

The second point concerns the study of environmental knowledge. The content and structure of the academic knowledge of local environmental knowledge is itself linked to the institutional framework within which it is generated and used. The request to make local knowledge available for development has in many cases led to a toolbox approach to its study that, in my view, underestimates the complex social embeddedness of knowledge. What distinguishes a system of knowledge from others is how activities such as observing, reasoning, assessing, or generalizing merge with ordinary or specialized social practice. STS has advocated studying how these processes work in the construction of scientific knowledge. The same can be done in the case of local knowledge. The idea of a social nature of environmental knowledge therefore suggests an anthropological and holistic fieldwork approach that builds on language acquisition and the long-term observation of knowledge in action.

Responses to this article can be read online at: http://www.ecologyandsociety.org/issues/responses. php/7056

\footnotetext{
Acknowledgments:

I would like to thank the journal's anonymous reviewers and Imogen Bellwood-Howard, Patrick Eisenlohr, Christian Meyer, and Mark Moritz for commenting on earlier drafts of this article. I am also grateful to the Deutsche Forschungsgemeinschaft for their support of research initiatives that have contributed to this study.
} 


\section{LITERATURE CITED}

Agrawal, A. 1995. Dismantling the divide between indigenous and scientific knowledge. Development and Change 26:413-439. http://dx.doi.org/10.1111/j.1467-7660.1995.tb00560.x

Akrich, M. 2000. The de-scription of technical objects. Pages 205-224 in W. E. Bijker and J. Law, editors. Shaping technology/ building society: studies in sociotechnical change. MIT Press, Cambridge, Massachusetts, USA.

Austin, J. L. 1962. How to do things with words. Oxford University Press, Oxford, UK.

Barth, F. 1966. Models of social organization. Royal Anthropological Institute Occasional Paper 23, Royal Anthropological Institute, London, UK.

Barth, F. 1975. Ritual and knowledge among the Baktaman of New Guinea. Yale University Press, New Haven, Connecticut, USA.

Behnke, R. H., and I. Scoones. 1993. Rethinking range ecology: implications for rangeland management in Africa. Pages 1-30 in R. H. Behnke, I. Scoones, and C. Kerven, editors. Range ecology at disequilibrium: new models of natural variability and pastoral adaptation in African savannas. Overseas Development Institute, London, UK.

Berger, P. L., and T. Luckmann. 1967. The social construction of reality. A treatise in the sociology of knowledge. Doubleday, Garden City, New York, USA.

Berkes, F. 2008. Sacred ecology: traditional ecological knowledge and resource management. Second edition. Taylor \& Francis, Washington, D.C., USA.

Berkes, F., J. Colding, and C. Folke. 2008. Introduction. Pages 1-29 in F. Berkes, J. Colding, and C. Folke, editors. Navigating social-ecological systems: building resilience for complexity and change. Cambridge University Press, Cambridge, UK.

Berlin, B. 1992. Ethnobiological classification: principles of categorization of plants and animals in traditional societies. Princeton University Press, Princeton, New Jersey, USA.

Bijker, W. E., T. P. Hughes, and T. J. Pinch, editors. 2012. The social construction of technological systems: new directions in the sociology and history of technology. Anniversary edition. MIT Press, Cambridge, Massachusetts, USA.

Bonfiglioli, A. M. 1981. Ngaynaaka: herding according to the Wodaabe. U.S. Agency for International Development, Tahoua, Niger.

Bonfiglioli, A. M. 1990. Pastoralisme, agro-pastoralisme et retour: itinéraires sahéliens. Cahiers des sciences humaines 26:255-266.

Bonfiglioli, A. M., C. White, L. Loutan, and J. J. Swift. 1984. The Wodaa6e. Pages 255-529 in J. J. Swift, editor. Pastoral development in central Niger: report of the Niger Range and Livestock Project. Ministry of Rural Development and U.S. Agency for International Development, Niamey, Niger.

Callon, M. 1986. Some elements of a sociology of translation: domestication of the scallops and the fishermen of St Brieuc Bay. Pages 196-233 in J. Law, editor. Power, action and belief: a new sociology of knowledge? Routledge, London, UK.
Collins, H. M. 1983. The sociology of scientific knowledge: studies of contemporary science. Annual Review of Sociology 9:265-285. http://dx.doi.org/10.1146/annurev.so.09.080183.001405

Dupire, M. 1957. Pharmacopée peule du Niger et du Cameroun. Bulletin de l' IFAN 19:382-418.

Dupire, M. 1972. Les facteurs humaines dans l'économie pastorale: Études nigériennes 6. Centre Nigérien de Recherches en Sciences Humaines, Niamey, Niger.

Dupire, M. 1996. Peuls nomades: études descriptive des Wođaabe du Sahel nigérien. Second edition. Karthala, Paris, France.

Duranti, A. 1997. Linguistic anthropology. Cambridge University Press, Cambridge, UK.

Gadgil, M., F. Berkes, and C. Folke. 1993. Indigenous knowledge for biodiversity conservation. Ambio 22:151-156.

Garfinkel, H. 1967. Studies in ethnomethodology. Prentice-Hall, Englewood Cliffs, New Jersey, USA.

Gulliver, P. H. 1975. Nomadic movements: causes and implications. Pages 369-386 in T. Monod, editor. Pastoralism in tropical Africa. Oxford University Press, London, UK.

Have, P. ten. 2007. Doing conversation analysis: a practical guide. Second edition. Sage, London, UK.

Hutchins, E. 1995. Cognition in the wild. MIT Press, Cambridge, Massachusetts, USA.

Ingold, T. 2000. The perception of the environment. Essays on livelihood, dwelling and skill. Routledge, London, UK. http://dx. doi.org/10.4324/9780203466025

Johnson, M. 1992. Lore: capturing traditional environmental knowledge. Dene Cultural Institute, International Development Research Centre, Hay River, Northwest Territories, Canada.

Knight, G. C. 1980. Ethnoscience and the African farmer: rationale and strategy. Pages 203-229 in D. Brokensha, D. M. Warren, and $\mathrm{O}$. Werner, editors. Indigenous knowledge systems and development. University Press of America, Lanham, Maryland, USA.

Krätli, S. 2008. Cattle breeding, complexity and mobility in a structurally unpredictable environment: the Wodaa6e herders of Niger. Nomadic Peoples 12:11-41. http://dx.doi.org/10.3167/ np.2008.120102

Krätli, S., and N. Schareika. 2010. Living off uncertainty: the intelligent animal production of dryland pastoralists. European Journal of Development Research 22:605-622. http://dx.doi. org/10.1057/ejdr.2010.41

Latour, B. 1987. Science in action: how to follow scientists and engineers through society. Harvard University Press, Cambridge, Massachusetts, USA.

Latour, B. 1991. Technology is society made durable. Pages 103-131 in J. Law, editor. A sociology of monsters. Essays on power, technology, and domination. Routledge, London, UK.

Latour, B., and S. Woolgar. 1986. Laboratory life: the construction of scientific facts. Second edition. Princeton University Press, Princeton, New Jersey, USA. 
Law, J. 1992. Notes on the theory of the actor-network: ordering, strategy, and heterogeneity. Systems Practice 5:379-393. http://dx. doi.org/10.1007/BF01059830

Law, J. 2012. Technology and heterogenous engineering: the case of Portuguese expansion. Pages 105-128 in W. E. Bijker, T. P. Hughes, and T. J. Pinch, editors. The social construction of technological systems: new directions in the sociology and history of technology. Anniversary edition. MIT Press, Cambridge, Massachusetts, USA.

Liebenberg, L. 1990. The art of tracking. The origin of science. Philip, Claremont, South Africa.

MacKenzie, D. A., and J. Wajcman, editors. 1999. The social shaping of technology. Second edition. Open University Press, Buckingham, UK.

Martin, G. J. 1995. Ethnobotany: a methods manual. Chapman and Hall, London, UK.

McCorkle, C. M. 1989. Towards a knowledge of local knowledge and its importance for agricultural RD\&E. Agriculture and Human Values 6:4-12. http://dx.doi.org/10.1007/BF02217664

Merton, R. K. 1942. Science and technology in a democratic order. Journal of Legal and Political Sociology 1:115-126.

Meyer, C. 2010. Self, sequence and the senses: universal and culturespecific aspects of conversational organization in a Wolof social space. Thesis. University of Bielefeld, Bielefeld, Germany.

Meyer, C., and N. Schareika. 2009. Neoklassische Feldforschung: Die mikroskopische Untersuchung sozialer Ereignisse als ethnographische Methode. Zeitschrift für Ethnologie 134:79-129.

Moritz, M., P. Scholte, I. M. Hamilton, and S. Kari. 2013. Open access, open systems: pastoral management of common-pool resources in the Chad basin. Human Ecology 41:351-365. http:// dx.doi.org/10.1007/s10745-012-9550-Z

Niamir, M. 1990. Herder's decision-making in natural resources management in arid and semi-arid Africa. Food and Agriculture Organization of the United Nations, Rome, Italy.

Pinch, T. J., and W. E. Bijker. 1984. The social construction of facts and artefacts: or how the sociology of science and the sociology of technology might benefit each other. Social Studies of Science 14:399-441. http://dx.doi.org/10.1177/030631284014003004

Randall, R. A. 1976. How tall is a taxonomic tree? Some evidence for dwarfism. American Ethnologist 3:543-553. http://dx.doi. org/10.1525/ae.1976.3.3.02a00100

Richards, P. 1985. Indigenous agricultural revolution: ecology and food production in West Africa. Unwin Hyman, London, UK.

Richards, P. 1993. Cultivation: knowledge or performance. Pages 61-78 in M. Hobart, editor. An anthropological critique of development: the growth of ignorance. Routledge, London, UK.

Schareika, N. 2001. Environmental knowledge and pastoral migration among the Wodaa6e of south-eastern Niger. Nomadic Peoples 5:65-88. http://dx.doi.org/10.3167/082279401782310934

Schareika, N. 2003a. Know to move, move to know. Ecological knowledge and herd movement strategies among the Wodaabe of southeastern Niger. FAO Inter-departmental Working Group on Biological Diversity for Food and Agriculture, Rome, Italy.

Schareika, N. 2003b. Westlich der Kälberleine. Nomadische Tierhaltung und naturkundliches Wissen bei den Wodaabe Südostnigers. Lit, Berlin, Germany.

Schareika, N. 2010a. Pulaaku in action: words at work in Wodaa6e clan politics. Ethnology 49:207-227.

Schareika, N. 2010b. Rituell gezeugt: Verwandtschaft als symbolische Interaktion bei den Wodaa6e Südostnigers. Pages 93-117 in E. Alber, B. Beer, J. Pauli, and M. Schnegg, editors. Verwandtschaft heute. Reimer, Berlin, Germany.

Schareika, N. 2011. Subject, leader, chief, commander: Wodaa6e politics between clan and communal structure. Pages 477-508 in E. Jul-Larson, P.-J. Laurent, P.-Y. Le Meur, and E. Léonard, editors. Une anthropologie entre pouvoirs et histoire. Conversations autour de Jean-Pierre Chauveau. Karthala, Paris, France.

Scoones, I. 1996. New directions in pastoral development in Africa. Pages 1-36 in I. Scoones, editor. Living with uncertainty: new directions in pastoral development in Africa. Intermediate Technology, London, UK.

Sillitoe, P. 1998. The development of indigenous knowledge: a new applied anthropology. Current Anthropology 39:223-252. http://dx.doi.org/10.1086/204722

Stenning, D. J. 1957. Transhumance, migratory drift, migration; patterns of pastoral Fulani nomadism. Journal of the Royal Anthropological Institute of Great Britain and Ireland 87:57-73. http://dx.doi.org/10.2307/2843971

Stenning, D. J. 1958. Household viability among the pastoral Fulani. Pages 92-119 in J. Goody, editor. The development cycle in domestic groups. Cambridge University Press, Cambridge, UK.

Thébaud, B. 2002. Foncier pastoral et gestion de l'espace au Sahel: Peul du Niger oriental et du Yagha burkinabé. Karthala, Paris, France.

Turner, M. D., and P. Hiernaux. 2008. Changing access to labor, pastures, and knowledge: the extensification of grazing management in Sudano-Sahelian West Africa. Human Ecology 36:59-80. http://dx.doi.org/10.1007/s10745-007-9149-y

Warren, D. M. 1991. Using indigenous knowledge in agricultural development. World Bank Discussion Papers 127, World Bank, Washington, D.C., USA.

Warren, D. M., D. Brokensha, and L. J. Slikkerveer. 1995. The cultural dimension of development: indigenous knowledge systems. Intermediate Technology, London, UK.

Watson-Gegeo, K. A., and D. W. Gegeo. 1990. Shaping the mind and straightening out conflicts: the discourse of Kwara'ae family counseling. Pages 161-213 in K. A. Watson-Gegeo, editor. Disentangling: conflict discourse in Pacific societies. Stanford University Press, Stanford, California, USA.

Wright, G. A., and J. D. Dirks. 1983. Myth as environmental message. Ethnos: Journal of Anthropology 48(3-4):160-176. http:// dx.doi.org/10.1080/00141844.1983.9981261 


\section{Appendix 1. Text passages in Fulfulde.}

Mbohori: welaa boo. e toy tagu wadata? ko yahari yoolde, min ngi'aay don maa to gaynaako boo laggira witta, kat. amman daa ba do'o woyla banye do'o no hebortono goddum ko faraw-faraw.

Rebo: dow Nga Salkiiji?

Nyaleega: Nga Salkiiji dadey maa dewaayno nanmi (amman mi nan). dadey maa dewaay. insi moye? insi Garga min Kootala, don iwi o hodoyi hakkunde Nga Buddere e Ngel Gunju. nyannan min potootiri yeeso do'o to ngiida min kodi dow Ngaya'en; min dali be e be ndaara bamdi. Garga wari don to baali muudum don min nginti. o wi'i yam: do'o hokkere tuufi be do'o dow Nga Salkiiji. o wi'i: ngan arande maa nyannde dadey maa dewaay sam. mbada don boo woyla faa to habaru haadi. hokkere tuufi be, o nanaay to ndiyam woni. non Garga wi'i. tunda ngiidaa jawdi e moosi wadi do'o (...)

Rebo: mhmm.

Mbohori: naa ngo'ol woylawol na?

Rebo: hmm.

Mbohori: aa, ngol walaa ndunngu.

Nyaleega: to miin, haala hannde a yidaa ka. ka laptoto, ka fe6nay tagu. amman Egere iwoyi Haadndu, min ngintidi luumo. to haala, naa um gaynaako w'i maa ka, naa a wi'ata ka lenyol. ka welaa.

o wi'i yam gada Haadndu, ndunngu kam buranngu walaa amman hokkere walaa, hokkere walaa, [ndunngu] woodi walaa faa o wari Kanadaa. o wi'i: woyla Haadndu, gada Kawlayel asamaare nanngoyi de'e balde (ngodnga do'o nga ngi'inooden kama), o wi'i, gada ton asamaare nanngoyi faa waddi e soofa nga'a nga Haadndu, don nde helti.

o wi'i baawowol ngol don daande yoolon - no Egere wi'i yam fa - o wi'i, dum fuu dum puddum, dum nanndi i ndunngu. mbi'imi na'i no njahay na njahataa? o wi'i, na'i yo njahay kat. non gada nden walaa mo mbi'imi ka, mi salii, mi anndi mi hoolaaki mo.

Mbohori: ka Egere?

Nyaleega: ka Egere. naa um gaynaako.

Kebbe: ay boo nde'e [ruulde] maa nde nyannde luumo don to iwoyi no tobtoto dum.

Nyaleega: o wi'i na'i no tiimoyay kat. o wi'i yam, o wi'i waane: miin kam naa mi gaynaako, dum tagu si'ire. mbi'imi mo: a'a gaynako fuu no go'o. o wi'i yam: dow yoolde wadi tuppe, karal boo wadi geene. no Egere wi'i yam. fewana en, goongana en.

Laabi: Mulliwol wi'i e dum woodi, ... amman mo baali fuu yahataa, Ndoowi'en no njabay di. Ndoowi'en nja6ay tagu baali.

Nyaleega: baali e njaboo, dum haba kay.

Nyaleega: e kadi, no mbadeten: do'o jo'oni to fa'a fuu badaaki; miin, kul en ngi'i kama um sokanto'en, no mbi'imi mbaden, ngoonsen me. to en ngoonsi boo, Rebo, raa immanooden ma mbeela nga'a nga seeden yarnugo.

to en ngaddi e ma'aga en kebi dum woodi kama koo tuppo-tuppo kanyum e kebba nga'a nga be mbi'ata gada en koday. ngoosooden ma ladde, ngi'en no den ngontiri, don en kebay ngoosoyooden. ngoosooden ma ladde koo en keba, ngi'en ko woodi e lardu, ngi'en ko woodi e ladde.

Rebo: ngan don boo han tagu e heba dum?

Nyaleega: too.

Rebo: ngan don boo kul ... tagu yidataa nga.

Nyaleega: kadi jawdi tan hadata nga. ay be mbooru kam wutiibe nga, be mbooru no wutiibe.

Kebbe: be mbooru fa dow amin tokki.

Nyaleega: be mbooru no nguti.

Muudi: koo naa ngan daa'e?

Nyaleega: kannga, nga go'ota. 
Gayro: be mbooru nden ma gada e nga'a Nga Loppiri do'o keedi.

Nyaleega: fommbina?

Gayro: ii boo. ben don, to be njanaay e ma'aga ma keenya, ben don um hodaybe dow ma'aga. nden ma Ngukoori'en e Jijiiru do'o takkoyi ngari don. duudbe boo be daama, Ngambijaari'en keedi be do'o. ngan don boo, kollel ngel don ngel luumo koowa yi'i nga, ngan don kam tagu hodataa nga. de'e tuppe de'e de ngi'eten de ngalaa ...

Nyaleega: de ngalaa. um kebbo kon tan.

Gayro: kebbo kon ma kon ngalaa, um innde tan. bana keenya nder ma'aga mbeetmi e mi dari? Ndoowi'en ma kebaay to kodi.

Gayro: e to. to yeeso ma'agel oya woni, dow yoolde. kanko fuu e Gado.

Nyaleega: kanko maa mbooru o woodi?

Gayro: aa, Kedi walaa mbooru. ... mi fottu bayargol mu'um kanyum.

Kebbe: don kam to min keedi wa'aroyi yeeso, na'i keppataa to kodi: amman kat tagu sey hula gada mbooru, sey jonte, amman dum buri do'o. miin kam naa mi gaynaako, naa mi woosoto, naa gam ma koomi.

Nyaleega: Kebbe am, giide fuu no go'ote.

Kebbe: tagu to raari baaba Muudi, mo durataa na'i maa i anndi ko di nyaamata di kaara?

Nyaleega: ee aan kadi gaynaako mo durataa meedi.

Kebbe: amman ni kat tagu to hulaay nyaw dum bappa, to hulaay mbooru, to hulaay jonte ...

Nyaleega: du'um boo ay tagu hulata.

Baaki: na'i boo mo dabare nde woodaa fuu, mo dabare nde woodaa fuu yi'ataa di faa abidi.

mo dabare nde wooda? o solana tatum:

du'um o solana seede, o wi'a tinaa seede keewi mo jiiba o yiilataako i duuniya, o'o, o wadtaa dikkiiji o wadtaa tappangel.

didi ma'jum, o solana haala, haala tan o yidi, o yi'rataake sefre hoore ma'ko faa lehidi tagge.

tati ma'jum, tati ma'jum Mbohri, o raarataa geene, a nani, tati ma'jum o raarataa geene, o raarataa geene Mbohri, kul o raarataa geene, a tawrataa mo daangol yeeso ma'ko kippiingol faa lehidi tagge.

faa wi'ee wehde wo're o tappi nayi, jowi koo joweego'o, faa wehde wo're o tappa sappo, faa o tappa i dow, too naa seede - kul a yi'i o tappi dindon naa seede o raarata. daareydo seede bangungel fuu yo heltey wa'ta i jiiba, bangungel fuu o heltey o wa'ta i jiiba. to, faa abidi, nde tawdaa mo fuu non tawataa emo yiila wasere feere ma'ko.

kandon kam dum laahira, walaa mo di nganyi say mo dabare hallunde. walaa mo di nganyi. 